\title{
EFFECT OF IRRIGATION INTERVALS AND FOLIAR SPRAY WITH SALICYLIC AND ASCORBIC ACIDS ON MAIZE
}

\author{
Abo-Marzoka E.A, Rania F.Y., El-Mantawy and Iman M.Soltan \\ Dep. Crop Physiology. Field Crop Research Institute \\ Agric.Res.Center Giza,Egypt.
}

\begin{abstract}
The present study was carried out at the Experimental Farm of Sakha Agriculture Research Station Kafr El-sheikh, Egypt during the growing seasons 2013 and 2014 to study the effect of foliar spray of salicylic and ascorbic acids (vitamin C) on growth, yield and yield components of maize (Zea mays) hybrid SC.128 under irrigation interval treatments. The experimental design was a split-plot with four replicates. The main plots were devoted to irrigation intervals:- 1irrigation every 15 days (control). 2- irrigation every 20 days (moderate water deficit). 3- irrigation every 25 days (severe water deficit).While the sub plots were assigned to foliar applications of salicylic acid (SA) and ascorbic acid (AA):

1- sprayed with water (control). 2 - sprayed with 100 ppm of salicylic acid (SA).

3- sprayed with 200 ppm of salicylic acid (SA) 4- sprayed with 100 ppm of ascorbic acid (AA). 5- sprayed with 200 ppm of ascorbic acid (AA). 6- sprayed with 100 ppm of salicylic acid (SA). + foliar with 100 ppm of ascorbic acid(AA).Following data were recorded :- plant height, leaf area, photosynthetic pigments (chl. a, chl. b and total chl.),ear height, ear weight, ear length, ear diameter, number of grains ear $^{-1}$, grains weight ear $^{-1}$, 100-grains weight and grain yield (ard./fed). All growth parameters were significantly reduced with widening intervals irrigation 25 days while ascorbic acid, particularly at 200 ppm tended to mitigate the adverse effect of water deficit on growth and yield components to maize plants. It is suggested that ascorbic acid could be a promising material used to reduce the harmful effect of water stress on the growth and yield of maize plants.
\end{abstract}

Keywords: water stress, salicylic acid (AS), ascorbic acid(AA), Zea mays, growth, yield.

\section{INTRODUCTION}

Maize is $\mathrm{C}_{4}$ and a water use efficient plant but is highly susceptible to water stress at its reproductive stage because of its unusual floral structure (Nemeth et al., 2002). The most critical period for water stress in maize is ten to fourteen days before and after flowering .Because grain yield of maize is highly correlated with kernel number per plant .This indicating 
the importance of an adequate supply of water during flowering (Karam et al., 2003). The requirement of irrigation for maize varies with soil type and agro-climatic conditions. Irrigation at such critical stage of floral development resulted in better growth in maize (Stone et al., 2001). Water is one of the most abundant compounds on the ground and $2 / 3$ of the ground-level was surrounded or covered with water, but in most part of the world, lack (shortage) of water is a factor which is limit the production of the agricultural products (Reddy et al., 2004). Lack (shortage) of water in Egypt is accounted as a factor which limit the plantation and growth of the agricultural plants. Plants often suffer from water deficit stress, and the severity of the resulting damage varies depending on the intensity and duration of the stress. Other than the apparent effects of drought stress, the effects of water deficit are not well understood at the biochemical and molecular levels (AbdElbaki et al., 2000 ; Bismillah et al. 2001 and Reddy et al., 2004). Various physiological practices are applied to alleviate the adverse effects of water deficit stress on the normal functioning of plants. For example, plant growth regulators have been applied to plants as a means of improving the growing of those plants. Indeed, there is evidence that the proper application of plant growth regulators can increase plant tolerance to environmental stresses such as drought, heavy metals, salinity, chilling and water-logging (Campos et al., 2004 , Darvishan et al., 2013 and Yaghoubian et al., 2014 ).

Salicylic and ascorbic acids, are an important phytohormones that plays a key role in response to biotic stresses and pathogenesis. Apart from this role, recent studies have demonstrated that SA also participates in the signaling of abiotic stress responses, such as drought, high and low temperature, salinity, ozone, UV radiation, and heavy metals. Darvishan et al., (2013) and Yaghoubian et al., (2014).

The present work aim to use the power full of both salicylic and ascorbic acids in alleviation of the adverse effect of water deficit on maize growth and productivity.

\section{MATERIALS AND METHODS}

The present study was carried out at the Experimental Farm of Sakha Agriculture Research Station KafrElsheikh ,Egypt during the two summer growing seasons 2013 and 2014 to study the effect of foliar spray of salicylic and ascorbic acids on growth, yield and yield components of maize plant hybrid SC.128 grown under irrigation intervals water deficit was created by widening irrigation intervals. 
The preceding crop was wheat in the two seasons. A split-plot with four replicates was adopted. The main plots were determine intervals irrigation: - 1- irrigation every15 days as (control), 2- irrigation every 20 days (moderate water deficit) 3-irrigation every 25days (severe water deficit). While, sub plots were randomly assigned to : 1- control (water sprayed). 2- spray with $100 \mathrm{ppm}$ of salicylic acid. 3spray with 200 ppm of salicylic acid. 4- spray with 100 ppm of ascorbic acid . 5- spray with $200 \mathrm{ppm}$ of ascorbic acid . 6- spray with $100 \mathrm{ppm}$ of salicylic acid $+100 \mathrm{ppm}$ of ascorbic acid. The plot area was $14 \mathrm{~m}^{2}$ i.e. 5 rows $4 \mathrm{~m}$ long and $0.70 \mathrm{~m}$ apart. Sowing dates were achieved on June $10^{\text {th }}$ and $15^{\text {th }}$ in the two successive seasons (2013 and 2014), respectively. Two seeds were hand sown in hills spaced at $25 \mathrm{~cm}$ on ridges at $0.70 \mathrm{~m}$ apart. Plants were thinned to one plant/hill 21 days after planting. Nitrogen fertilizers at the rate of $120 \mathrm{~kg}$ nitrogen fed ${ }^{-1}$ of urea $(46.5 \%)$ was applied in two equal portions before the first and the second irrigations. The treatments SA and AA were applied as foliar sprayed twice after 30 and 45 days after planting. Plant samples were taken from the outer two ridges of each plot at 60,75 days and 85 DAP then the following data were measured recorded. plant height $(\mathrm{cm})$ , leaf area $\left(\mathrm{dm}^{2}\right.$ plant $\left.^{-1}\right)$ and chlorophyll content of leaves. Some physical and chemical properties of the experimental soil were analyzed using the methods described by Black et al., (1982) and the obtained results are given in Table (1). The monthly averages of water factors for KafrEl-Sheikh region during 2013 and 2014 seasons were shown in Tables (3and 4).

Table (1): Mechanical and chemical analysis of soil at the experimental sites during 2013 and 2014seasons

\begin{tabular}{|c|c|c|}
\hline Determination & 2013 & 2014 \\
\hline \multicolumn{3}{|l|}{ Mechanical analysis: } \\
\hline \multicolumn{3}{|l|}{ Soil fraction: } \\
\hline Sand \% & 17.00 & 20.00 \\
\hline Silt \% & 25.10 & 23.30 \\
\hline Clay \% & 57.90 & 56.70 \\
\hline \multicolumn{3}{|l|}{ chemical analysis: } \\
\hline $\mathrm{pH}$ & 8.10 & 8.50 \\
\hline E.C. $\mathrm{mm} \mathrm{hos} / \mathrm{cm}$ & 2.00 & 1.70 \\
\hline Organic matter (O.M) \% & 1.30 & 1.53 \\
\hline Available N ppm & 29.00 & 30.00 \\
\hline Available P ppm & 15.00 & 13.00 \\
\hline Available K ppm & 300.00 & 350.00 \\
\hline
\end{tabular}


Table (2): The monthly averages of water factors for Kafr El-Sheikh region during 2013 and 2014 seasons

\begin{tabular}{|c|c|c|c|c|c|c|c|}
\hline \multicolumn{2}{|c|}{ Month } & \multicolumn{3}{|c|}{ Temperature $\mathrm{C}^{\sigma}$} & \multirow{2}{*}{$\begin{array}{l}\text { Relative } \\
\text { humidity }\end{array}$} & \multirow{2}{*}{$\begin{array}{l}\text { Wind } \\
\text { speed }\end{array}$} & \multirow[t]{2}{*}{ Pan evaporation } \\
\hline & & Max. & Min. & Mean & & & \\
\hline \multirow[t]{2}{*}{ June } & \multirow{2}{*}{$\begin{array}{l}2013 \\
2014\end{array}$} & 33.7 & 21.7 & 27.7 & 46 & 3.42 & 8.26 \\
\hline & & 36.8 & 24.3 & 30.6 & 42 & 3.07 & 8.09 \\
\hline \multirow{2}{*}{$\begin{array}{l}\text { July } \\
2013\end{array}$} & \multirow[b]{2}{*}{2014} & 37.4 & 27.1 & 32.3 & 48 & 2.98 & 8.36 \\
\hline & & 39.1 & 30 & 34.6 & 46 & 2.75 & 8.31 \\
\hline \multirow[t]{2}{*}{ Aug. } & \multirow{2}{*}{$\begin{array}{c}2013 \\
2014\end{array}$} & 39.9 & 29.8 & 34.9 & 50 & 2.81 & 7.69 \\
\hline & & 40.2 & 28.7 & 34.5 & 49 & 2.34 & 7.73 \\
\hline \multirow[t]{2}{*}{ Sep. } & \multirow{2}{*}{$\begin{array}{l}2013 \\
2014\end{array}$} & 38.2 & 28.9 & 33.6 & 49 & 2.41 & 6.02 \\
\hline & & 36.6 & 29.3 & 33.0 & 46 & 2.27 & 6.14 \\
\hline \multirow[t]{2}{*}{ Oct. } & \multirow{2}{*}{$\begin{array}{l}2013 \\
2014\end{array}$} & 35.4 & 27.4 & 31.4 & 47 & 2.41 & 5.6 \\
\hline & & 33.9 & 28.6 & 31.3 & 48 & 2.38 & 5.8 \\
\hline
\end{tabular}

${ }^{\star}$ Max = maximum, Min=minimum ${ }^{*}$.Mgro meteorological data climatic factor from Sakha Station(A.R.C).

Table (3): Some soil moisture constants and bulk density for the experimental field during 2013 and 2014 seasons

\begin{tabular}{|c|c|c|c|c|}
\hline $\begin{array}{l}\text { Soil depth } \\
\text { (cm) }\end{array}$ & $\begin{array}{c}\text { Field capacity } \\
\text { wt. } \%\end{array}$ & $\begin{array}{c}\text { Wilting point } \\
\text { wt. \% }\end{array}$ & $\begin{array}{c}\text { Bulk density } \\
\mathrm{g} \mathrm{cm}^{2}\end{array}$ & $\begin{array}{c}\text { Available } \\
\text { moisture } \mathrm{m} \mathrm{m}\end{array}$ \\
\hline \multicolumn{5}{|c|}{2013 season } \\
\hline $0-15$ & 39.42 & 20.17 & 1.39 & 47.6 \\
\hline $15-30$ & 34.19 & 18.46 & 1.42 & 44.3 \\
\hline $30-45$ & 31.82 & 16.21 & 1.37 & 39.8 \\
\hline $45-60$ & 30.29 & 15.36 & 1.40 & 34.1 \\
\hline \multicolumn{5}{|c|}{2014 season } \\
\hline $0-15$ & 42.82 & 21.4 & 1.43 & 49.6 \\
\hline $15-30$ & 40.11 & 20.3 & 1.41 & 44.8 \\
\hline $30-45$ & 38.92 & 18.8 & 1.37 & 42.1 \\
\hline $45-60$ & 36.40 & 16.1 & 1.32 & 39.2 \\
\hline
\end{tabular}

At age 60, 75 and 85 days after planting (DAP) a sample of five representative plants was taken at random from each plot to determine:

1- The total chlorophyll pigments were determined according to the methods of and calculated according to the equations following Moran (1982).

Chl a=12.7(O.D)664-2.79(O.D)647= $\mathrm{mgL}^{-1}$

Chl b=20.7(O.D)647-4.62(O.D)664 $=\mathrm{mgL}^{-1}$

Total chl. $=17.9$ (O.D)647-8.08(O.D)664 $=\mathrm{mgL}^{-1}$

2- leaf area ( $\mathrm{dm}^{2} /$ plant ).

3- Ea leaf area $\left(\mathrm{cm}^{2}\right)$ : was determined by the methods described by Quarrie and Jones (1979).

4-Relative yield reduction (RYR): was estimated by using the formula suggested by Fisher and Maurer(1978): 
$R Y R \%=\{(Y i-a d q-Y i . d e f) / Y i-a d q\}$

where, Yi- adq was the yield of treatment under adequate water; Yi.def was the yield of treatments under deficit water; adq was the overall yield of treatments under adequate water and def was the overall yield of treatments under deficit water .

$\mathrm{DD}=$ (yield under non-stress - Yield under stress).

\section{Yield and its components:-}

At harvest done at 122 and 120 days after sowing for two successive seasons, respectively taken ten guarded plants were taken from the $2^{\text {nd }}$ and $3^{\text {rd }}$ ridges in each plots to determine plant height, ear height, ear length ear weight, ear diameter, number of grains/ear, grains weight/ear, 100 -grains weight and grain yield (ard./fed.) one $\mathrm{ardb}=190 \mathrm{~kg}$ which was adjusted to $15.5 \%$ moisture content.

All collected data were subjected to statistical analysis of variance according to Gomez and Gomez (1984). The treatments average were compared using LSD test at 0.05 level of significant.

\section{Effect on growth}

\section{RESULTS AND DISCUSSION}

Data in Tables $(4,5$ and 6$)$ indicated that, severe water deficit (25days irrigation intervals') resulted in plant growth. All plant growth characters including plant height, leaf area per plant significantly decreased due to water deficit. The highest value of plant height and leaf area per plant recorded for maize plants irrigated every 15 days .The lowest reduction in growth parameters was observed under severe water stress ( irrigation at 25 days) .On the other side, foliar application of salicylic or ascorbic acids, showed significant increase in growth characters i.e. plant height, leaves concentrations of chl. a, chl. $\mathrm{b}$ as well as total chl. and leaf area per plant at 60,75 and 85 DAP compared with untreated plants in the two seasons. In this the highest respect, increase in such characters was obtained in plants sprayed with $100 \mathrm{ppm}$ salicylic acid $+100 \mathrm{ppm}$ ascorbic acid. The depressive effect of water stress on growth parameters could be attributed to the drop in leaf water content and the reduction in the assimilation of nitrogen compounds (Reddy et al., 2004).It also, affect the rate of cell division and enlargement. Drought stress also reduced the uptake of essential elements and affected photosynthetic capacity as well as induced excessive accumulation of intermediate compounds such as reactive oxygen species (Khalifa et al., 2002 and El-Sobky et al.,2014 ), which cause oxidative damage to DNA, lipid and proteins and consequently a decrease in plant growth. Finally, water stress 
leads to increases in abscisic acid which cause an inhibition of the growth. The enhanced production of ROS during water stress lead to the progressive oxidative damage and ultimately cell death and growth suppression (Araus et al. 2012). Foliar spray of ascorbic acid (ASA) in most cases resulted in a significant increase in maize plants growth parameters under normal or stressed conditions. The effect is more pronounced at $(200 \mathrm{ppm})$ dose of AA as it increased uptake of water and essential nutrients through adjusting cell osmotic potential, and reducing the accumulation of harmful of the reactive oxygen species (ROS) by increasing antioxidants and enzyme. Salicylic and ascorbic acid can mitigate the adverse effects of drought through increasing the content of IAA and GA3 and decreasing ABA level, which may be involved in protecting the photosynthetic apparatus and consequently increasing the photosynthetic pigments (Campos et al.,2004). They concluded that, chlorophyll content of plants treated with vitamins (such as ascorbic acid) was increased due to the protection effect of these vitamins.( Yaghoubian et al. 2014). reported that, ascorbic acid can detoxify and neutralize the effect of the reactive oxygen species by prevention of free radicals activity, leading to increase in chlorophyll content of vitamin- treated plants. They also found that, application of salicylic acid and vitamin C (ascorbic acid) was effective to mitigate the adverse effect of abiotic stress on plant growth due to increased leaf area and improved chlorophyll a, b and total chlorophyll contents.

Table (4): Effect of foliar spray with salicylic and ascorbic acids under irrigation intervals on some growth characters at 60 days after sowing during 2013 and 2014 seasons

\begin{tabular}{|c|c|c|c|c|c|c|c|c|}
\hline \multirow[t]{2}{*}{ Treatments } & $\begin{array}{c}\text { Chl.a } \\
\left(\mathrm{mg} / \mathrm{dm}^{2}\right)\end{array}$ & $\begin{array}{c}\text { Chl.b } \\
\left(\mathrm{mg} / \mathrm{dm}^{2}\right)\end{array}$ & $\begin{array}{l}\text { Total } \\
\text { Chl. }\end{array}$ & $\begin{array}{c}\text { Leaf area } \\
\left(\mathrm{dm}^{2}\right)\end{array}$ & $\begin{array}{c}\text { Chl.a } \\
\left(\mathrm{mg} / \mathrm{dm}^{2}\right)\end{array}$ & $\begin{array}{c}\text { Chl.b } \\
\left(\mathrm{mg} / \mathrm{dm}^{2}\right)\end{array}$ & $\begin{array}{l}\text { Total } \\
\text { Chl. }\end{array}$ & $\begin{array}{c}\text { Leaf area } \\
\left(\mathrm{dm}^{2}\right)\end{array}$ \\
\hline & \multicolumn{4}{|c|}{2013 season } & \multicolumn{4}{|c|}{2014 season } \\
\hline \multicolumn{9}{|l|}{ Irrigation intervals (A) } \\
\hline Irrigation every 15 days & 2.692 & 1.795 & 4.487 & 18.70 & 3.018 & 1.761 & 4.779 & 20.19 \\
\hline Irrigation every 20 days & 1.573 & 1.049 & 2.622 & 16.41 & 2.086 & 1.217 & 3.303 & 17.72 \\
\hline Irrigation every 25 days & 1.501 & 1.001 & 2.502 & 14.05 & 1.394 & 0.813 & 2.207 & 15.17 \\
\hline LSD at 0.05 & 0.302 & 0.135 & 0.337 & 1.568 & 0.195 & 0.098 & 0.192 & 1.378 \\
\hline \multicolumn{9}{|l|}{ Foliar treatments (B) } \\
\hline Foliar with water & 1.425 & 0.950 & 2.376 & 15.32 & 1.88 & 1.097 & 2.977 & 16.54 \\
\hline SA at $100 \mathrm{ppm}$ & 1.904 & 1.269 & 3.173 & 15.98 & 2.244 & 1.309 & 3.553 & 17.26 \\
\hline SA at $200 p p m$ & 2.159 & 1.439 & 3.598 & 16.25 & 2.303 & 1.343 & 3.646 & 17.55 \\
\hline $\mathrm{AA}$ at $100 \mathrm{ppm}$ & 1.631 & 1.087 & 2.718 & 16.55 & 2.028 & 1.183 & 3.211 & 17.87 \\
\hline $\mathrm{AA}$ at $200 \mathrm{ppm}$ & 2.129 & 1.420 & 3.549 & 16.93 & 2.132 & 1.243 & 3.375 & 18.28 \\
\hline SA at $100 p p m+100 A A p p m$ & 2.285 & 1.524 & 3.809 & 17.27 & 2.409 & 1.405 & 3.814 & 18.66 \\
\hline LSD at 0.05 & 0.498 & 0.332 & 0.830 & 2.96 & 0.251 & 0.146 & 0.397 & 2.155 \\
\hline Interaction (A XB) LS D at 0.05 & 0.768 & 0.628 & 1.224 & 3.255 & 1.61 & 0.496 & 1.188 & 2.817 \\
\hline
\end{tabular}

(SA ) Salicylic Acid, (AA) Ascorbic Acid 
Table (5): Effect of foliar spray with salicylic and ascorbic acids under irrigation intervals on some growth characters at 75 days after sowing during 2013 and 2014 seasons

\begin{tabular}{|c|c|c|c|c|c|c|c|c|}
\hline \multirow[t]{2}{*}{ Treatments } & $\begin{array}{c}\text { Chl.a } \\
\left(\mathrm{mg} / \mathrm{dm}^{2}\right)\end{array}$ & $\begin{array}{c}\text { Chl.b } \\
\left(\mathrm{mg} / \mathrm{dm}^{2}\right)\end{array}$ & $\begin{array}{l}\text { Total } \\
\text { Chl. }\end{array}$ & $\begin{array}{l}\text { Leaf } \\
\text { area } \\
\left(\mathrm{dm}^{2}\right)\end{array}$ & $\begin{array}{c}\text { Chl.a } \\
\left(\mathrm{mg} / \mathrm{dm}^{2}\right)\end{array}$ & $\begin{array}{c}\text { Chl.b } \\
\left(\mathrm{mg} / \mathrm{dm}^{2}\right)\end{array}$ & $\begin{array}{l}\text { Total } \\
\text { Chl. }\end{array}$ & $\begin{array}{l}\text { Leaf } \\
\text { area } \\
\left(\mathrm{dm}^{2}\right)\end{array}$ \\
\hline & \multicolumn{4}{|c|}{2013 season } & \multicolumn{4}{|c|}{2014 season } \\
\hline \multicolumn{9}{|l|}{ Irrigation treatments $(\mathrm{A})$} \\
\hline Irrigation every 15 days & 3.365 & 2.468 & 5.833 & 22.91 & 3.722 & 2.264 & 5.982 & 25.2 \\
\hline Irrigation every 20 days & 1.967 & 1.442 & 3.409 & 20.45 & 2.573 & 1.565 & 4.138 & 22.5 \\
\hline Irrigation every 25 days & 1.877 & 1.376 & 3.253 & 17.08 & 1.719 & 1.046 & 2.765 & 18.79 \\
\hline LSD at 0.05 & 0.253 & 0.185 & 0.438 & 1.477 & 0.107 & 0.065 & 0.172 & 1.417 \\
\hline \multicolumn{9}{|l|}{ Foliar treatments (B) } \\
\hline Foliar with water & 1.782 & 1.307 & 3.089 & 18.48 & 2.319 & 1.41 & 3.729 & 20.33 \\
\hline SA at $100 \mathrm{ppm}$ & 2.380 & 1.745 & 4.125 & 19.21 & 2.768 & 1.683 & 4.451 & 21.13 \\
\hline SA at 200ppm & 2.698 & 1.979 & 4.677 & 19.99 & 2.84 & 1.727 & 4.567 & 21.99 \\
\hline AA at $100 \mathrm{ppm}$ & 2.038 & 1.495 & 3.533 & 20.35 & 2.50 & 1.521 & 4.022 & 22.39 \\
\hline AA at $200 \mathrm{ppm}$ & 2.662 & 1.952 & 4.614 & 21.22 & 2.62 & 1.599 & 4.228 & 23.34 \\
\hline SA at $100 p p m+100 \mathrm{AA} p p m$ & 2.857 & 2.095 & 4.952 & 21.63 & 2.97 & 1.807 & 4.778 & 23.8 \\
\hline LSD at 0.05 & 0.622 & 0.456 & 0.791 & 2.696 & 0.309 & 0.188 & 0.498 & 2.367 \\
\hline $\begin{array}{l}\text { Interaction(AXB) LS D at } \\
0.05\end{array}$ & 1.04 & 0.787 & 0.898 & 3.489 & 0.532 & 0.602 & 0.963 & 2.867 \\
\hline
\end{tabular}

(SA) Salicylic Acid, (AA) Ascorbic Acid

The plant water status is dependent on: the soil moisture content, the capacity for water absorption by roots, and the hydraulic conductivity of root and shoot tissues. Water potential is often used as a measure of the water status of a plant. Plants are seldom fully hydrated. During periods of drought, they suffer from water deficits that lead to inhibition of plant growth and photosynthesis. Several physiological changes occur as plants experience increasingly drier conditions. Cell expansion is most affected by water deficit. In many plants reductions in water supply inhibit shoot growth and leaf expansion but stimulate root elongation. Drought does impose some absolute limitations on physiological processes, although the actual water potentials at which such limitations occur vary with species. Water stress typically leads to an accumulation of solutes in the cytoplasm and vacuole of plant cells, thus allowing the cells to maintain turgor pressure despite low water potential. Some physiological processes appear to be influenced directly by turgor pressure. However, the existence of stretch-activated signaling molecules in the plasma membrane suggests that plant cells may sense changes in their water status via changes in volume, rather than 
Table (6): Effect of foliar spray with salicylic and ascorbic acids under irrigation intervals on some growth characters at 85 days after sowing during 2013 and 2014seasons

\begin{tabular}{|c|c|c|c|c|c|c|c|c|}
\hline \multirow[t]{2}{*}{ Treatments } & $\begin{array}{c}\text { Chl.a } \\
\left(\mathrm{mg} / \mathrm{dm}^{2}\right)\end{array}$ & $\begin{array}{c}\text { Chl.b } \\
\left(\mathrm{mg} / \mathrm{dm}^{2}\right)\end{array}$ & $\begin{array}{l}\text { Total } \\
\text { Chl. }\end{array}$ & $\begin{array}{c}\text { Leaf } \\
\text { area }\left(\mathrm{Cm}^{2}\right. \\
)\end{array}$ & $\begin{array}{c}\text { Chl.a } \\
\left(\mathrm{mg} / \mathrm{dm}^{2}\right)\end{array}$ & $\begin{array}{c}\text { Chl.b } \\
\left(\mathrm{mg} / \mathrm{dm}^{2}\right)\end{array}$ & $\begin{array}{l}\text { Total } \\
\text { Chl. }\end{array}$ & $\begin{array}{c}\text { Eer leaf } \\
\text { area } \\
\left(\mathrm{Cm}^{2}\right) \\
\end{array}$ \\
\hline & \multicolumn{4}{|c|}{2013 season } & \multicolumn{4}{|c|}{2014 season } \\
\hline \multicolumn{9}{|l|}{ Irrigation treatments (A) } \\
\hline Irrigation every 15 days & 3.589 & 2.647 & 6.237 & 5.29 & 3.822 & 2.464 & 6.286 & 5.44 \\
\hline Irrigation every 20 days & 2.098 & 1.547 & 3.645 & 4.42 & 2.642 & 1.704 & 4.346 & 3.23 \\
\hline Irrigation every 25 days & 2.002 & 1.476 & 3.478 & 3.67 & 1.766 & 1.138 & 2.904 & 3.07 \\
\hline LSD at $5 \%$ & 0.270 & 0.199 & 0.468 & 1.836 & 0.110 & 0.071 & 0.180 & 1.123 \\
\hline \multicolumn{9}{|l|}{ Foliar treatments (B) } \\
\hline Foliar with water & 1.9 & 1.402 & 3.302 & 3.89 & 2.381 & 1.535 & 3.916 & 3.1 \\
\hline SA at $100 \mathrm{ppm}$ & 2.539 & 1.872 & 4.411 & 4.20 & 2.569 & 1.656 & 4.225 & 3.55 \\
\hline SA at 200ppm & 2.878 & 2.123 & 5.001 & 4.39 & 2.701 & 1.741 & 4.442 & 4.048 \\
\hline AA at $100 \mathrm{ppm}$ & 2.174 & 1.603 & 3.778 & 4.58 & 2.917 & 1.881 & 4.798 & 4.06 \\
\hline AA at $200 \mathrm{ppm}$ & 2.839 & 2.094 & 4.933 & 4.72 & 2.842 & 1.833 & 4.675 & 4.174 \\
\hline SA at $100 p p m+A A$ at $100 p p m$ & 3.047 & 2.247 & 5.294 & 4.98 & 3.052 & 1.968 & 5.02 & 4.56 \\
\hline LSD at $5 \%$ & 0.664 & 0.489 & 1.153 & 2.696 & 0.318 & 0.205 & 0.523 & 1.630 \\
\hline Interaction (AXB) L S D at 0.05 & 1.68 & 0.827 & 1.324 & 3.503 & 0.522 & 0.415 & 0.910 & 2.235 \\
\hline
\end{tabular}

(SA ) Salicylic Acid, (AA) Ascorbic Acid

by responding directly to turgor pressure (ljaz et.al. 2014). The effectiveness of plants in moderating water loss while allowing sufficient $\mathrm{CO}_{2}$ uptake for photosynthesis can be assessed by a parameter called the Transpiration ratio. This value is defined as the amount of water transpired by the plant divided by the amount of carbon dioxide assimilated by photosynthesis. For plants in which the first stable product of carbon fixation by photosynthesis, giving a transpiration ratio .

\section{Yield and its components}

Data in Table (7) showed that the plant height (cm),ear height (cm),ear length $(\mathrm{cm})$ grains weight /ear, ear diameter, number of grainslear, ear weight, 100-grains weight, grain yield were affected by water stress and spray plants with salicylic acid and ascorbic acid counteracted this negative effect of drought. All yield components decreased under the two water stress levels (20 and 25 days irrigation intervals). It is well known that water severe ( water deficit irrigation every 25 days) negatively affected all growth parameters and development, therefore, yield and its components were significantly depressed under suck treatment. drought stress. Grain weight of ear per plant significantly decreased with increasing water deficit, while foliar application of salicylic acid or ascorbic acid, especially at 200 ppm tended to reverse this negative effect and increased the yield . Previous studies reported that water stress reduced the yield of many crops (El-Sobky et al.,2014). The reduction yield may be due to the negative effect of water stress on the number of grains and number of corn/ plant as well as leaf area, resulting in a reduction in the supply of 
carbon assimilate and photosynthetic rate by plants and consequently less biomass

Table 7: Effect of irrigation intervals and foliar spray of salicylic and ascorbic acid on yield and yield components of maize plants during the two seasons 2013 and 2014

\begin{tabular}{|c|c|c|c|c|c|c|c|c|c|}
\hline Treatment & $\begin{array}{c}\text { Plant } \\
\text { height } \\
(\mathrm{cm})\end{array}$ & $\begin{array}{c}\text { Ear } \\
\text { height } \\
(\mathrm{cm})\end{array}$ & $\begin{array}{c}\text { Ear } \\
\text { weight } \\
(\mathrm{g})\end{array}$ & $\begin{array}{l}\text { Ear } \\
\text { length } \\
(\mathrm{cm})\end{array}$ & $\begin{array}{c}\text { Ear } \\
\text { diamete } \\
r \\
(\mathrm{~cm})\end{array}$ & $\begin{array}{c}100- \\
\text { Grainwt. } \\
(\mathrm{g})\end{array}$ & $\begin{array}{c}\text { No. of } \\
\text { grain/ea } \\
r\end{array}$ & $\begin{array}{c}\text { Grain } \\
\text { wt./ ear }\end{array}$ & $\begin{array}{c}\text { Grain } \\
\text { yield } \\
\text { ard/fed. }\end{array}$ \\
\hline \multicolumn{10}{|c|}{2013 season } \\
\hline \multicolumn{10}{|l|}{ Irrigation treatments (A) } \\
\hline Irrigation 15 days & 294.33 & 158.93 & 201.42 & 36.8 & 7.29 & 51.82 & 456.0 & 132.02 & 22.86 \\
\hline Irrigation 20 days & 245.72 & 132.69 & 173.71 & 25.6 & 6.40 & 36.03 & 317.2 & 81.48 & 16.42 \\
\hline Irrigation 25 days & 203.95 & 110.13 & 153.57 & 17.4 & 5.49 & 24.52 & 215.8 & 70.77 & 13.23 \\
\hline LSD at 0.05 & 13.488 & 8.434 & 1.491 & 2. 164 & 2.048 & 2.160 & 8.712 & 1.899 & 3.166 \\
\hline \multicolumn{10}{|l|}{ Foliar application (B) } \\
\hline foliar with water & 216.47 & 116.89 & 159.18 & 22.8 & 5.97 & 32.11 & 282.7 & 66.25 & 14.73 \\
\hline SA 100 ppm & 233.51 & 126.10 & 172.07 & 24.8 & 6.23 & 34.90 & 307.3 & 78.53 & 16.20 \\
\hline SA $200 \mathrm{ppm}$ & 244.22 & 131.88 & 176.37 & 26.1 & 6.34 & 36.78 & 338.4 & 99.48 & 16.80 \\
\hline AA 100 ppm & 254.46 & 137.41 & 178.92 & 27.3 & 6.45 & 38.46 & 323.5 & 100.44 & 17.94 \\
\hline AA $200 \mathrm{ppm}$ & 262.25 & 141.61 & 181.62 & 28.0 & 6.62 & 39.51 & 347.7 & 106.62 & 18.88 \\
\hline SA $100 \mathrm{ppm}+$ ASA $100 \mathrm{ppm}$ & 277.10 & 149.63 & 189.26 & 30.5 & 6.75 & 42.98 & 378.3 & 117.24 & 20.47 \\
\hline L.S.D at 0.05 & 17.88 & 10.72 & 2.57 & 2.5 & 2.201 & 3.591 & 13.428 & 2.290 & 5.08 \\
\hline \multicolumn{10}{|l|}{ Interaction (AXB) } \\
\hline L.S.D at $5 \%$ & 19.80 & 12.10 & 3.80 & 3.5 & 3.871 & 5.80 & 17.66 & 3.104 & 7.404 \\
\hline \multicolumn{10}{|c|}{2014 season } \\
\hline \multicolumn{10}{|l|}{ Irrigation treatments (A) } \\
\hline Irrigation every 15 days & 267.30 & 169.20 & 203.98 & 35.49 & 8.15 & 57.10 & 465.1 & 153.15 & 22.99 \\
\hline Irrigation every 20 days & 205.00 & 129.70 & 121.21 & 20.49 & 5.43 & 33.00 & 326.3 & 94.52 & 16.20 \\
\hline Irrigation every 25 days & 162.10 & 102.60 & 115.17 & 18.74 & 5.15 & 30.20 & 298.4 & 82.09 & 14.83 \\
\hline LSD at 0.05 & 10.468 & 9.273 & 1.917 & 2.217 & 1.832 & 3.787 & 6.793 & 3.892 & 4.042 \\
\hline \multicolumn{10}{|l|}{ Foliar application (B) } \\
\hline foliar with water & 180.70 & 114.30 & 116.37 & 18.87 & 5.06 & 30.40 & 300.5 & 76.84 & 15.41 \\
\hline foliar SA $100 \mathrm{ppm}$ & 192.00 & 121.50 & 132.94 & 22.19 & 5.58 & 35.70 & 353.5 & 91.09 & 16.60 \\
\hline foliar SA $100 \mathrm{ppm}$ & 231.30 & 146.40 & 151.81 & 25.90 & 6.43 & 43.50 & 412.6 & 115.40 & 17.64 \\
\hline foliar AA $100 \mathrm{ppm}$ & 209.00 & 132.20 & 152.25 & 26.05 & 6.46 & 41.70 & 430.5 & 116.51 & 18.80 \\
\hline foliar AA 200 ppm & 223.20 & 141.30 & 156.53 & 27.05 & 6.69 & 41.90 & 414.8 & 123.67 & 19.34 \\
\hline foliar SA100 ppm+AS100 ppm & 232.80 & 147.30 & 170.82 & 29.41 & 7.24 & 47.40 & 468.2 & 136.00 & 20.24 \\
\hline LSD at 0.05 & 14.10 & 13.50 & 2.36 & 3.62 & 2.92 & 5.80 & 7.65 & 5.802 & 6.90 \\
\hline \multicolumn{10}{|l|}{ Interaction (AXB) } \\
\hline L.S.D at 0.05 & 18.74 & 16.16 & 4.31 & 7.275 & 3.358 & 8.139 & 9.35 & 9.052 & 8.262 \\
\hline
\end{tabular}

(SA ) Salicylic Acid, (AA) Ascorbic Acid,

produced as well as decreased translocation of assimilates towards the developing crop parts. The depressive effect of water stress on yield could be also attributed to the inhibitory effect of drought on vegetative growth which be partly related to a significant reduction of foliar chlorophyll contents and nutrients concentration. Exogenous application of ascorbic acid under drought stress caused, increased all parameters of yield components as compared to the corresponding water stress level. This positive effect of salicylic, ascorbic acids on yield components could be attributed to its role as a cofactor for enzymes involved in photosynthesis, hormone biosynthesis, and the regeneration of antioxidants (Yaghoubian et al., 2014). Drought depression (DD) and Relative yield reduction (RYR\%)

Data in Table (8) clearly showed that, water deficit caused reduction in grain yield during the two growing seasons. The mean drought depression (DD) 6.44,6.79, 9.63 and $8.16 \%$ mean relative 
yield reduction(RYR) values were for 28.17,29.53,42.13 and $35.49 I_{2}$ and $I_{3}$ respectively corresponding to these results may be due to all yield components decreased under different water stress levels. It is well known that water severe (irrigation all 25 days ) affects negatively all growth parameters and development, therefore, yield and its components were significantly depressed under drought stress. These results are in harmony with those obtained by Habliza and Abdelhalim (2011). Water deficit is stressful, but too much water can also have several potentially negative consequences for a plant. Flooding and soil compaction result in poor drainage, leading to reduced $\mathrm{O}_{2}$ availability to cells. Flooding fills soil pores with water, reducing $\mathrm{O}_{2}$ availability. Dissolved oxygen diffuses so slowly in stagnant water that only a few $\mathrm{cm}$ of soil near the surface remain oxygenated. At low temperatures the consequences are relatively harmless. However, when temperatures are higher (greater than $20^{\circ} \mathrm{C}$ ), $\mathrm{O}_{2}$ consumption by plant roots, soil fauna, and microorganisms can totally deplete $\mathrm{O}_{2}$ from the soil in as little as 24 hours. Flooding sensitive plants. soil dries, its hydraulic conductivity decreases very sharply, particularly near the permanent wilting point (that is, the soil water content at which plant cannot regain turgor up on rehydration). Redistribution of water within the roots often occurs at night, when evaporative emend -deficient plants tend to become rehydrated at night, allowing leaf growth during the day. But at the permanent wilting point, water delivery to the roots is too slow to allow the overnight rehydration of plants that have wilted during the day. The tested treatments foliar application with SA or AA on maize plants gave increasing at Drought depression (DD), Relative yield Reduction (YR\%) in the two seasons. Thus, decreasing soil water conductivity hinders rehydration after wilting. results are in harmony with those obtained by (Darvishan et al., 2013 ljaz et al., 2014 and Yaghoubian et al., 2014). Plant nutrition is traditionally treated as two separate topics: organic nutrition and inorganic nutrition. Organic nutrition focuses on the production of carbon compounds, specifically the incorporation of carbon, hydrogen, and oxygen via photosynthesis, while inorganic nutrition is concerned primarily with the acquisition of mineral elements from the soil. Photosynthesis and the acquisition of mineral ions from the soil are so interdependent, however, that this distinction between organic and inorganic nutrition is more a matter of convenience than real. 
Table (8): Drought depression (DD) and Relative yield reduction (YR\%) as affected by irrigation intervals and foliar spray with SA and AA through 2013 and 2014 seasons

\begin{tabular}{|c|c|c|c|c|}
\hline \multirow[t]{2}{*}{ Treatments } & \multicolumn{2}{|c|}{2013 season } & \multicolumn{2}{|c|}{2014 season } \\
\hline & DD & YR\% & DD & YR\% \\
\hline \multicolumn{5}{|l|}{ Irrigation intervals } \\
\hline Irrigation at 20 days & 6.44 & 28.17 & 6.79 & 29.53 \\
\hline Irrigation at 25 days & 9.63 & 42.13 & 8.16 & 35.49 \\
\hline \multicolumn{5}{|l|}{ Sub stances } \\
\hline Foliar spray with water & 8.20 & 40.57 & 7.29 & 31.19 \\
\hline Foliar spray with $100 \mathrm{SA}$ & 7.50 & 35.38 & 7.31 & 30.76 \\
\hline Foliar spray with $200 \quad$ SA & 7.95 & 36.06 & 7.89 & 31.96 \\
\hline Foliar spray with $100 \mathrm{ppm}$ AA & 8.18 & 34.95 & 8.88 & 34.50 \\
\hline Foliar spray with 200ppm AA & 8.25 & 33.84 & 8.93 & 33.66 \\
\hline Foliar spray with $100 \mathrm{ppm} S \mathrm{SA}+100 \mathrm{ppmAA}$ & 8.20 & 31.63 & 8.95 & 32.35 \\
\hline \multicolumn{5}{|l|}{ Interaction (Axb) } \\
\hline Foliar spray with water & 7.31 & 36.19 & 5.50 & 28.28 \\
\hline Foliar spray with $100 \mathrm{SA}$ & 6.10 & 28.77 & 5.73 & 27.43 \\
\hline Foliar spray with $200 \quad$ SA & 6.45 & 29.25 & 6.33 & 28.23 \\
\hline Foliar spray with $100 \mathrm{ppm}$ AA & 6.29 & 26.89 & 7.70 & 31.53 \\
\hline Foliar spray with 200ppm AA & 6.39 & 26.21 & 7.74 & 31.05 \\
\hline Foliar spray with $100 p p m ~ S A+100 p p m A A$ & 6.21 & 23.97 & 7.71 & 29.87 \\
\hline \multicolumn{5}{|l|}{ Interaction $(\mathrm{AxC})$} \\
\hline Foliar spray with water & 9.08 & 44.95 & 9.08 & 34.09 \\
\hline Foliar spray with $100 \mathrm{SA}$ & 8.90 & 41.98 & 8.90 & 34.08 \\
\hline Foliar spray with $200 \quad$ SA & 9.45 & 42.86 & 9.45 & 35.68 \\
\hline Foliar spray with 100ppm AA & 10.06 & 43.00 & 10.06 & 37.46 \\
\hline Foliar spray with 200ppm AA & 10.11 & 41.47 & 10.11 & 36.26 \\
\hline Foliar spray with 100ppm SA+100ppm AA & 10.18 & 39.29 & 1.18 & 34.83 \\
\hline
\end{tabular}

(SA ) Salicylic Acid, (AA) Ascorbic Acid

In Conclusion irrigation of maize plants every 20 days with foliar application with 100 ppm salicylic acid plus 100 ppm ascorbic acid produced highest value of most of growth attributes, yield, it components maize hybrid "128" under KafrElsheikh conditions.

\section{REFERENCES}

Abd-El baki, G.K, F. Siefritz, H.M. Man, H. Weiner, R.Kaldenhoff, and W.M. Kaiser. (2000). Nitrate reeducates in Zea mays L. under salinity. Plant Cell Environ. 23:515-521.

Araus, J.L., M.D. Serret and G.O. Edmeades, (2012). Phenotyping maize for adaptation to drought. Front Physiol 3: 305. PubMed: 22934056.

Bismillah KM, Hussain N and M. Iqbal (2001). Effect of water stress on growth and yield components of maize variety YHS 202. Journal of Research in Science 12: 15-18.

Black, C.A., D.D.Evan, L.E. Ensinger, J. L.White and F.E.Clark.(1982) .Methods of soil analysis (chemical and microbiology properties, part (2). Amer. Soc. of Agron. Inc., Publisher Madison, Wisconsin, USA. 
Campos H, Cooper M, Habben JE, Edmeades GO and JR Schussler (2004). Improving drought tolerance in maize: a view from industry. Field Crops Res90:19-34.

Darvishan,M.,Moghadam ,H and H. Zahdi (2013) .The effect of foliar application of ascorbic acid

(vitamin C) on physiological and biochemical changes of corn (Zea mays L.) under irrigation

withholding in different growth stages .Maydica 58.195-200.

El-Sobky, E.A.M.E.M. Zadan, A.A. Abdel- Galil and H.G. Geweifel, (2014) . Effect of irrigation

interval ,organic maturing and nitrogen fertilization level on yield and yield attributes of maize

Zagazig .J. Agric. Res.,41(1): 1-20.

Esmail N., Mojdeh B. and T.Elnaz (2012). The effects of plant growth promoting on some of traits

in maize (cv.S.C.704)under drought stress condition European Journal of Experimental Biology, 2

(4):875-881.

Fisher, R.A and R. Maurer, (1978) .Drought resistance in spring wheat cultivars. I. Grain yield

responses in spring wheat. Australian J. Agric. Sci.29:892-912.

Gomez, K.A. and A.A. Gomez, (1984). Statistical procedures for agricultural Research $2^{\text {nd }}$ John Wiley \& Sons. Inc. New York.

Habliza A.A. and Abdalhady K.Abdelhalim, (2011).Productivity response of some maize

(Zea mays L.) hybrids to stress and non stress irrigation water .Alex. J.Agric.Res.56(1)17-25.

ljaz,A.nBasra,S.M.,Abdul Wahid, (2014).Exogenous application of ascorbic acid, salicylic acid and

hydrogen peroxide improves the productivity of hybrid maize at low temperature

stress.Int.J.Agric.,4 825-830.

Karam F., Breidy J., Stephan C. and J. Rouphael (2003). Evapotranspiration, yield and water use

efficiency of drip irrigated maize in the Bekaa Valley of Lebanon. Agricultural Water

Management 63.122-137.

Khalifa,K.I.,G.M.A.Mahgoub,and A.M.Tarrad (2002).Maize hybrid as influenced by drought stress

under drib irrigation at Nubaria region . J. Agric. Sci. Mansoura Univ.,27:2041-2052.

Moran,R.(1982).Formulae for determination of chlorophyllous pigments extracted with $\mathrm{N}, \mathrm{N}$ - dimethyl formamide .plant physiol, (69),1376-1381.

Nemeth, M., T. Janda, E. Horváth, E. Páldi and G. Szalai, (2002). Exogenous salicylic acid 
increases polyamine content but may decrease drought tolerance in maize. Plant Sci.,162: 569-

574.

Quarrie,S.A. and H.G. Jones (1979).Genotypic variation in leaf water potential, stomata conductance

and abscisic acid concentration in spring wheat subjected to artificial drought stress. Ann.Bot.,44: 323-327.

Reddy, A.R., K.V. Chaitanya and M.Vivekanandan, (2004). Droughtinduced responses of photosynthesis and antioxidant metabolism in higher plants. J. Plant Physiol, 161: 1189-202.

Stone PJ, Wilson DR, Jamieson PD and Gillespie RN (2001). Water deficit effects on sweet maize

Canopy development. Australian Journal of Agricultural Research 52115-126.

Yaghoubian ,H.,Moghadam,H. and H. Zahedi (2014). The effect of foliar application of Salicylic

acid on physiological and biochemical changes of corn (Zea mays L.) under irrigation withholding

in different growth stages. Journal of Applied Science and Agriculture, 9(9): 27-34.

$$
\text { تأثير فترات الري والرش الورقي بحض السالسليك وحمض الاسكوربيك على الثيل }
$$

السيد عبد المقصود ابومرزوقة- رانيا فاروق يوسف المنطاوى- إيمان محمد كمال الدين سلطان

قسم بحوث فسيولوجيا المحاصيل ـ معهد بحوث المحاصيل الحقلية ـ مركز البحوث الزراعية ـ

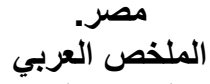

أجريت تجربة حقلية بمزرعة محطة البحوث الزرأية بسخا خلال موسمين 2014/2013م

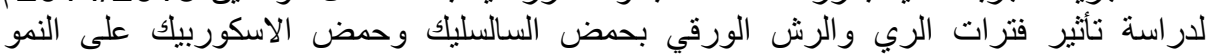

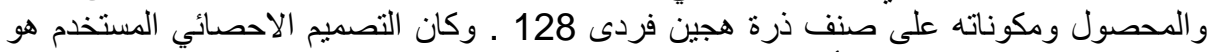

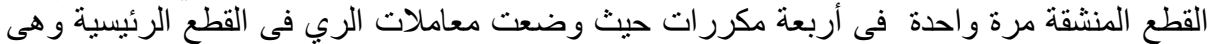

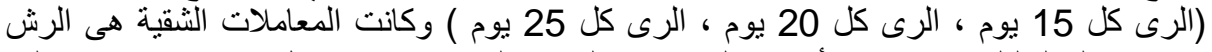

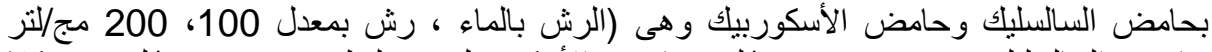

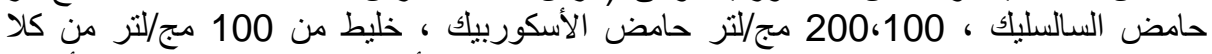

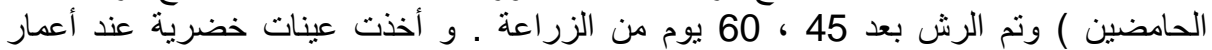

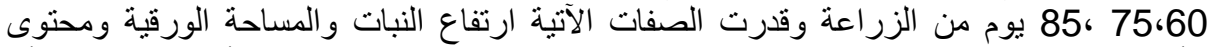

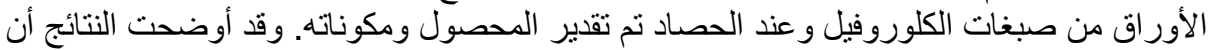

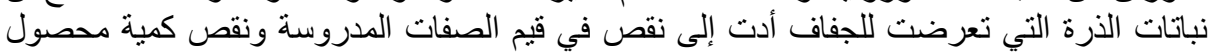

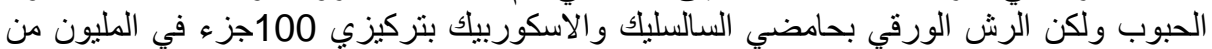

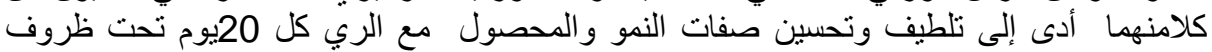

